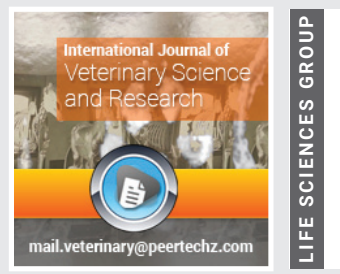

\title{
Review on the epidemiology of Bovine Rotavirus and its public health significance
}

\author{
Abebe Garoma Gichile* \\ National Animal Health Diaginostic and Investigation Center, Sebeta, Ethiopia
}

Received: 27 October, 2021

Accepted: 04 January, 2022

Published: 05 January, 2022

*Corresponding author: Abebe Garoma Gichile, National Animal Health Diaginostic and Investigation Center, Sebeta, Ethiopia,

E-mail: garomaabebe@gmail.com

Keywords: Epidemiology; Public health; Rotavirus; Strains; Diagnostic methods

Copyright License: (c) 2022 Gichile AG. This is an open-access article distributed under the terms of the Creative Commons Attribution License, which permits unrestricted use, distribution, and reproduction in any medium, provided the original author and source are credited.

https://www.peertechzpublications.com

\section{Check for updates}

\begin{abstract}
A literature review was made to assess the epidemiology, public health importance, diagnostic and control methods of bovine rotavirus. Rotavirus is the genus name under the family Reoviridae which is characterized by segmented genome. The emergence of new serotypes of the virus is related to the segmented nature of the viral genome which allows reassortment during mixed infections. The rotavirus genome consists of 11 double-stranded RNA gene segments encoding 6 nonstructural (NSP1-6) and 6 structural (VP1-4, VP6-VP7) proteins. Rotavirus A is a zoonotic disease and in children less than five years old, human rotavirus is reported to be the most common cause of gastritis. In animals, rotavirus infection usually affects calves within four weeks of age, causing huge economic losses due to death, reduction in weight gain and treatment costs. Bovine rotaviruses are globally distributed and cattle strains have been classified into $12 \mathrm{G}$ types and $11 \mathrm{P}$ types and among them $\mathrm{G} 6$, G8 and G10, and P [1], P [5] and P [11] are commonly prevalent bovine strains. However, the presence of $14 \mathrm{G}$ type and $17 \mathrm{P}$ type serotypes from human have reported in different surveillance studies worldwide. Among these, combinations of G1P [8], G2P [4], G3P [8], G4P [8], G9P [8] and G12P [8] are the most common human strains which are responsible for majority of human Rotavirus diseases. The virus is primarily transmitted by fecal-oral route or by direct contact. The excreta from infected animals and humans, excreta contaminated food; water, pasture and air are the potential source of infection for both animal and human rotaviruses. Age, seasonal pattern, strain diversity, poor herd management and housing system, host nutritional and immunological factors are important risk factors associated with rotavirus disease occurrences. The widely used diagnostic methods for detection of rotavirus antibody in human and animals are Enzyme-Linked Immunosorbent Assay (ELISA) and immune-chromatography while the presence of the rotavirus/antigen is identified by Enzyme Immunoassay (EIA). Electron Microscopy (EM), polymerase chain reaction (PCR) and nucleic acid hybridization. Vaccination is the primary strategy to prevent and control of bovine and human rotavirus infections. High level of antibody in pregnant animals is achieved through live attenuated and inactivated vaccines when administered at the late stage of pregnancy. In human, the two currently used vaccines are the RV5 vaccine (USA) and the RV1 vaccine (Belgium) types.
\end{abstract}

\section{Introduction}

Virus particles having a similar morphology with Rota viruses were reported in dairy calves in 1969 and human rotavirus cases were diagnosed in 1973 for the first time [1].

The genus Rotavirus within the family Reoviridae comprises seven rotavirus species [2]. Each rotavirus species is related with diarrhea. From the seven serotypes species, A type have been found both in animals and human [3].

Animal rotavirus mostly affect young animals specially calves with 4weeks [4]. The common variations and diversity are considered due to the point mutations [5]. Epidemiological studies of the virus in world are especially in some Asia, Sub Saharan Africa, and Latin America [6]. A ten years review [7]. In Africa human rotavirus revealed a greater diversity of rotavirus. The percentage of Rota combinations accompanied by the presence of multiple rotavirus $\mathrm{P}$ or $\mathrm{G}$ types.

In general, during the past 40-45 years, enormous researches and epidemiological surveillances have been conducted on the distribution, zoonotic importance, advanced diagnostic techniques and vaccine production. The paper summarizes the current information on rotavirus diseases with particular epidemiology and its public health importance in addition; it also highlights on the diagnostic methods and control strategies of the disease. Therefore, the objectives of 
the paper were: summarizing the current information on Rota virus disease with particular emphasis on the epidemiology and its public health importance and to highlight on the diagnostic method and control strategies of the disease.

\section{Literature review}

Etiology: An etiological agent called bovine rotaviruses which causes severe gastroenteritis and diarrhea [8]. Rotavirus agents under the family Reoviridae. The genus has 7 species (A to $\mathrm{G}$ ) or sometimes called groups. Each species especially the species rotavirus A contains different strains and genotypes.

Classification: The virus is to classify to groups, subgroups and its serotypes. The group and subgroup specificity are present on the inner capsid VP6. Thus, currently only rotavirus groups $\mathrm{A}, \mathrm{B}$ and $\mathrm{C}$ have been identified as human and animal pathogens, while groups D, E, F, and G have only been identified in animals and birds [9].

The structures of rotavirus: The rotavirus structure is $3 \mathrm{D}$ capsid protein structures [10]. Similarly, the virus structurally with dsRNA genome and the exact mechanisms of rotavirus genome assortment, packaging and particle assembly await exploration [11] Figures 1,2.

\section{Pathogenesis}

The pathogenesis of the disease is multifactorial it depends on the age of the host, and particular viral gene products [14]. Concluded that the genes encoding the mouse VP4 and NSP1were determinants for efficient replication in suckling mice. Factors of the disease mechanism are: mal-adsorption following destruction of epithelium and villus ischemia [15] and activation of the enteric nervous system [16].

Recently, the pathogenesis of the symptom vomiting has also been elucidated by observations that RV can infect the enterochromaffine cells in the gut and stimulate the production of 5-hydroxytryptamin (serotonin) which in turn activates vagal afferent nerves and stimulates brain stem structures controlling vomiting [17]. Biliary Atresia (BA) can be induced in newborn mice by RV infection, leading to obstructive cholangiopathy, the severity of which depends on the host's age at the time of infection and also on the presence and potency of innate immune responses [18].

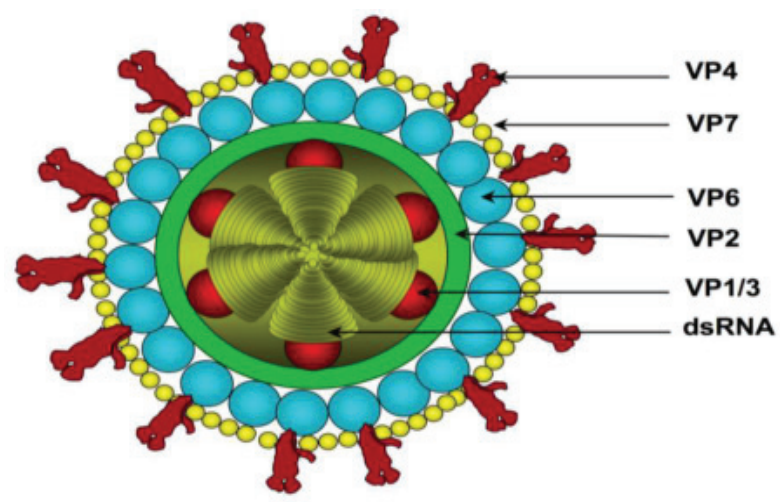

Figure 1: Schematic depiction of the structure of mature rotavirus particles. Source: [12]
Epidemiology of bovine rotavirus: Rotavirus causes diarrhea in calves and leads to a serious problem in newly born calves and a cause of economic loss, because of mortality, treatment costs, and poor growth. The epidemiology of animal rotaviruses is suggestive and investigated virus infections are those affecting cattle, swine, horse, and partly goats, sheep and camelides. Virus distributions is depend on the magnitude of the disease, in developed and developing countries a global survey showed that G1, G2, G3 and G4 were the most common worldwide genotypes of rotaviruses while G8 was relatively high in Africa [19].

Mode of transmission: The virus is transmitted in interspecies ways with a possibility of cross-species transmission. The interspecies transmission and subsequent reassortments are the important mechanisms driving the diversity of rotaviruses and enabling the emergence of new pathogenic strains with altered virulence [20]. Additionally, it transmitted by fecal-oral route or by direct contact [21].

\section{Risk factors}

Age: Younger animals were highly infected with Rota virus infection, mostly within the first 4 weeks [22].

Seasonal pattern: The rotavirus infection is occurred during the autumn to spring season. In temperate zone the virus shows seasonal patterns, with the epidemic peaks being more prominent during cold months. In subtropical and tropical settings, seasonality is less apparent [23].

Strain Diversity: the virus is diverse with their antigens. In developed countries a single genotype predominates at a geographic site. However, in developing countries, no single prevailing strain [24].

\section{Symptoms, laboratory diagnosis and treatment}

Clinical symptoms: Rotavirus diarrhea in calves presents an acute disease having a very short incubation period of 1224 hours or at times ranging from 18-96 hours. Fortunately, most rotavirus infections are mild and self- limiting, although there is usually high morbidity. Variations in clinical disease observed in calves depend on several factors, including the difference in virulence among rotavirus strains, age of the host, host immune status, the dose of the inoculum, occurrence of mixed infections, environmental stress (weather conditions, housing, overcrowding) and nutrition. These factors, along with systemic consequences of electrolyte imbalances, fluid loss and metabolic acidemia, anorexia, profuse watery diarrhea, and various degrees of systemic dehydration [25]. In severe cases, death occurs as a result of electrolyte imbalances, dehydration, and cardiac arrest [26].

Rotavirus infections are often asymptomatic or mild in infants $<1$ month of age because of protection conferred by maternal antibodies that are transferred through the placenta breast milk [27]. In children, the manifestation of rotavirus disease ranges from no symptoms to mild, watery diarrhea of short duration and to severe diarrhea with vomiting and fever that can result in rapid dehydration with shock, electrolyte imbalance and death [28].

Citation: Gichile AG (2022) Review on the epidemiology of Bovine Rotavirus and its public health significance. Int J Vet Sci Res 8(1): 005-010. 


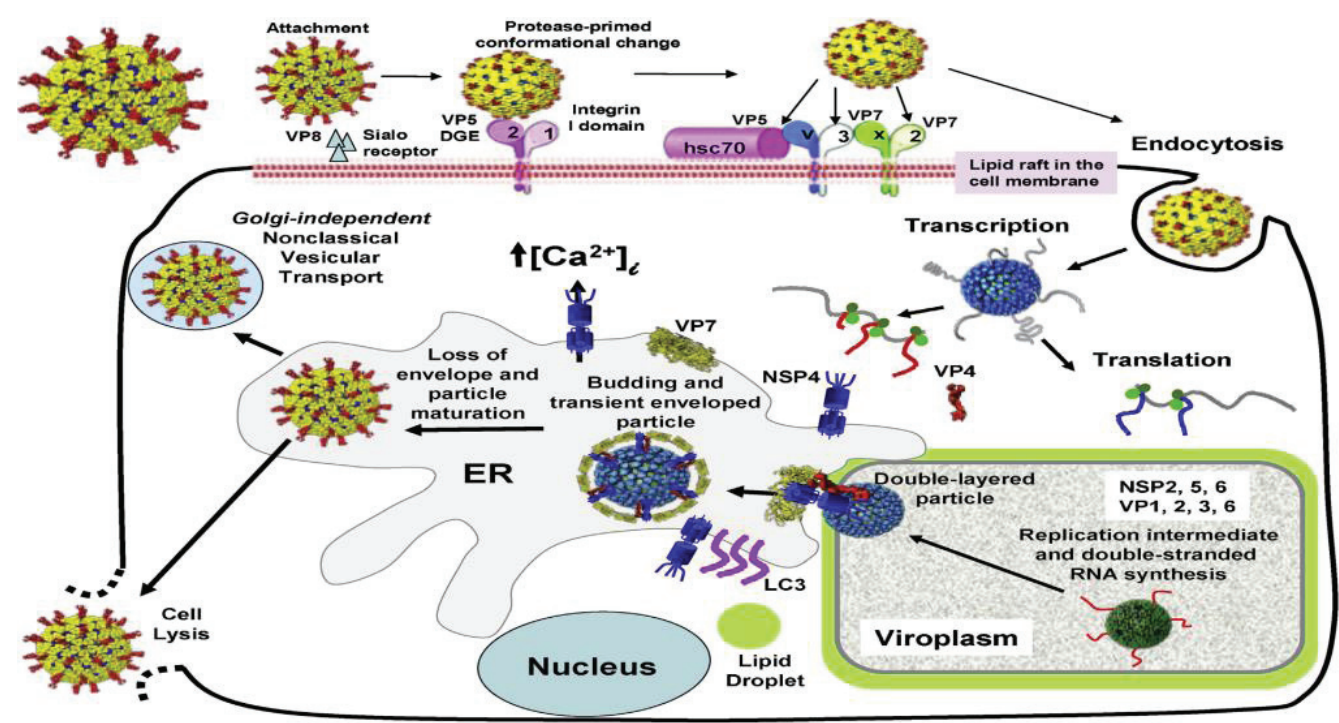

Figure 2: The rotavirus replication cycle.

Source: [13].

Laboratory Diagnostic methods: Laboratory diagnosis of rotavirus is very crucial for handling and preventing the occurrence of the disease in calves. It is challenging to diagnose target causal agents by clinical examination, so that laboratory test is an important tool to make a confirmatory diagnosis. This can be carried out by using various tests [29]. In general, the diagnosis of rotavirus is based on the identification and isolation of the virus in the faces [30].

Antigen Captured Enzyme-Linked Immunosorbent Assay (AgELISA): Ag-ELISA is an assay for rapidly detecting a pathogen in a clinical specimen based on antibody (e.g. Monoclonal antibody) recognition of the target antigen [31]. It has antibody attached to a solid surface of polystyrene plate and so that antibody captures the target antigen if present in. The enzyme tagged with the secondary antibody can cause a colorimetric visualization while reacting with the chromogen substrate which ensures the antigen-antibody reaction persistence. Antigen can be both qualitatively expressed and quantitatively estimated as Optical Density (OD) measured by a spectrometry positively correlates with the amount of antigen. In some situations, the commercial kit may be expensive, particularly for veterinary medicine [29].

Virus isolation: This test is a confirmatory diagnostic test that is still considered as "gold standard" for detecting the presence of viral pathogens in specimens [32]. Isolation of rotavirus in cell culture from fecal samples is the most conventional way of confirmatory diagnosis of rotavirus infection and gives the ultimate proof of virus association with the disease but it is less sensitive and is a laborious process. Specimens should be kept at a low temperature and in a transport medium during shipping to a diagnostic laboratory and delivered to the lab as soon as possible after collection [33]. Isolation of BRV is performed in rotavirus- specific primary cell cultures (calf kidney cells) and cell lines (MA 104-Simian origin, MDBK, HT-29, and PK-15). The presence of virus is suspected by the occurrence of Cytopathic Effect (CPE) including rounding and detachment of cells in cell culture system. Enhancement of CPE has been shown to be increased by incorporation of trypsin in the medium in few quantities and by the pretreatment of fecal samples with trypsin [34]. Viability of target virus in a specimen is critical for the success of virus isolation

Polymerase Chain Reaction (PCR): It is usually a detection method used for detecting rotavirus. It is a thermo cyclic enzymatic amplification of specific sequence of the target genes using a pair of oligonucleotide primers that hybridize on each cDNA strand of interest region in the genomic sequence. On the other way, rotavirus dsRNA can be detected in clinical specimens by extraction of viral RNA and analysis by electrophoresis on a polyacrylamide gel followed by silver staining. During electrophoresis, the 11 segments of the rotavirus dsRNA, which are negatively charged Molecules, separate according to size [35]. Patterns of dsRNA can be visualized in the gel by staining with bromide ion, because it forms a stable complex with nucleic acids. The gel can be stored after staining. Migration patterns of the segments of rotavirus dsRNA allow the classification of rotavirus strains into the "short" and "long" electropherotypes [6].

Electron Microscopy (EM): Most of bovine enteric viruses, like BRV are difficult to isolate or propagate in cell culture, but these viruses can be differentiated by their morphology under an electron microscope. Cost of electron microscopes and requirement of skilled laboratory personnel are still a challenge for the EM test being used as a routine diagnostic test [6]. This tool can identify and detects the virus based on morphological feature it has. Accordingly, two types of EM methods have been available: direct EM and immune-electron microscopy (IEM) [36] with positive and negative staining techniques used for visualization. The visualization of viruses, particularly non-cultivatable ones, is a major advantage of EM with rapid turnaround.

Treatment: There is no specific treatment for rotavirus 
infections. Treatment is based on providing supportive care and managing clinical signs and potential complications. In livestock and companion animals, fluid administration is essential to replace losses from diarrhea or vomiting, to correct acidosis and to restore electrolyte imbalance. Adequate sodium concentration and appropriate glucose to sodium ratios are the most important components of an efficient rehydration solution [37]. In young animals, administration of fluids can be performed by means of esophageal catheter; in older animals, intravenous administration is preferable. In affected piglets, administration of a plasma protein mixture, consisting of immunoglobulin, growth factors, and other biologically active peptides, has been advocated to enhance small intestine recovery [38]. Therefore most widely practiced treatment of Rota virus infections are antiviral therapy, Fluid administration and electrolyte management [39].

\section{Prevention and control}

The primary strategy to prevent and control of bovine and human rotavirus infections is through vaccination. However, in animals, vaccination strategy differs from the approaches implemented to protect infants and children against rotavirus disease in human [40].

To decrease the incidence of disease in the herd, a good producer should maximize colostrum transfer, increase environmental sanitation, reduce stressors such as overcrowding or poor nutrition and vaccinate bred cows for rotavirus at 60 and 30 days before calving [41].

To improve the passive immunization of calves against rotavirus and coronavirus as well as against different strains of E. coli vaccination of the pregnant dam can be proposed. Usually, cows are vaccinated twice ( 6 to 8 and 2 to 3 weeks) before parturition to stimulate the production of specific antibodies. The primary function of colostrum is to enhance the calf's immune system through the passive transfer of both antibody and cell-mediated immunity. Ideally, calves should receive colostrum from their dams although colostrum from several cows are often mixed and administration of colostrum feeding is the transmission of BVDV, bovine leukemia us, John's disease that can be spread by infected or purchased colostrum [42].

Colostrum is the source of nutrients and passively absorbed antibodies, which are critical to protect the newborn calf against infectious disease in the first weeks and months of life. The calf is born without most antibodies, including those that fight the infectious agents which cause diarrhea. The calf will acquire these antibodies only from colostrum. World Health Organization strongly recommends inclusion of $\mathrm{RV}$ vaccines into national immunization programs in all the regions where data on vaccine efficacy suggests a significant impact on public health and where infrastructure and financial resources are adequate [43].

\section{The status of the disease in Ethiopia}

Ethiopia is one of the five countries with greatest rotavirus burden worldwide and accounts for six percent of all rotavirus deaths globally. It is estimated that 28 percent of all underfive diarrheal disease hospitalizations in Ethiopia are caused by rotavirus [44]. Ethiopia has introduced the monovalent rotavirus vaccine in its national immunization program in November, 2013 to decrease the burden of rotavirus disease and mortality [45].

In a cross-sectional study carried out in Jima Hospital, Ethiopia, to reveal the prevalence of rotavirus infection among 154 infants and young children, rotavirus was detected in 26.6 $\%$ of fecal specimens and $90.2 \%$ (37/41) occurred in children under 2 years. The highest rate of rotavirus antigen detection was observed among 7-12 months of age group (34\%) [46]

On a study to see the epidemiology of rotavirus and Noro virus in Hawassa, Southern region from 200 under five children with diarrhea between 2008-2009, the prevalence of rotavirus was found to be $22 \%$ and the genotyping showed G3P [6] (48\%, globally uncommon strain), G1P [8] (27\%) and G2P [4] (7\%) being the strains most commonly identified [47]. Similarly, data collected from 2007-2011 in Addis Ababa from hospitalbased surveillance of rotavirus gastroenteritis among children less than five years showed that rotavirus was prevalent in $20 \%$ of children enrolled from 1,749 diarrheal samples [48].

A study revealed that children with vomiting had higher rotavirus diarrhea than without vomiting, Children with diarrhea episodes greater than 5 per 24 hours had higher rotavirus prevalence $(44.4 \%)$ and rotavirus detection was higher $(50 \%)$ among children with diarrhea duration of greater than 7 days before coming to health facilities [49]. However, the author concluded no child related risk factor was significantly associated with rotavirus diarrhea, but there was a difference in the positivity rate among different categories of children.

According to [50] the findings for rotavirus genotype distributions were distinct between Bahir Dar and Gondar. In total, wild type G3P, G2P, G9P, G12P, and G3P rotaviruses were detected in $68(60.2 \%), 21(18.6 \%), 13(11.5 \%), 9(8.0 \%)$ and $2(1.8 \%)$ of the positive samples, respectively while wild type G1P strains were absent. Another study in rotavirus-associated acute diarrhea outbreak investigation in West Shewa Zone of Oromia Region showed that the majority of the strains were G12P (25\%) and G-negative P (25\%) followed by G9P (19\%), G1P (13\%) and G3/G2 P, G12P and G-negative P (6\% each) [51].

In addition, the finding of another study [52], conducted in three hospitals of Addis Ababa showed that the most prevalent circulating strains were G12P in $2011(36 \%)$ and in $2012(27 \%)$, G2P (35\%) in 2013, G9P (19\%) in 2014, G3P and G2P (19\% each) in 2015, and G3P (29\%) in 2016. During the surveillance periods (2011-2017), G12P was detected as a dominant circulating strain followed by G3P and G1P.

\section{Conclusions and recommendations}

Rotaviruses are diverse genetically. All reviewed showed rotavirus is highly prevalent worldwide. The distribution of the disease is observed higher in sub-Saharan African countries as human vaccine coverage is very low and there is no commonly practiced vaccine for animals. In Africa, the most common 
human rotavirus strains observed and detected routinely are G1 and G2. In general, limitations in depth and number of researches are observed in sub-Saharan African counties and those reviewed studies focus on the prevalence and characterization of rotavirus strains with lack of epidemiological approach. There are no or few studies conducted on rotavirus in Ethiopia so far except a few hospitals based studies done on human rotaviruses. This shows bovine rotavirus is a neglected disease in Ethiopia despite the presence of high calf mortality due to diarrhea in different regions of the country.

Therefore, based on the review the following points are forwarded as a recommendation.

$\checkmark$ The animal health policy in the country should give attention for the implementation of surveillances and research studies on bovine rotavirus to improve the production and productivity so that the country gets benefited from the animal health sector.

$\checkmark$ Continued human rotavirus surveillance studies should be done to detect new strains circulating in the country.

1. Bovine rotavirus vaccine need to be introduced into Ethiopia after the different strains that cause calf diarrhea are detected and characterized.

$\checkmark$ The human vaccine which is currently delivering in Ethiopia.

\section{References}

1. Bishop R, Davidson GP, Holmes IH, Ruck BJ (1973) Virus particles in epithelial cells of duodenal mucosa from Children with acute non-bacterial gastroenteritis. Lancet 2: 1281-1283. Link: https://bit.ly/3FOttFQ

2. Kapikian AZ, Chanock RM (1996) Rotaviruses. Fields Virology, 4th ed Lippincott Williams and Wilkins, Philadelphia 1657-170.

3. Fagiolo A, Cristina R, Ogla L, Antonio B (2005) In: Antonio, B. (Ed.), Buffalo Pathologies. Buffalo Production and Research, FAO, Rome 249-296.

4. Martella V, Bányai K, Matthijnssens J, Buonavoglia C, Ciarlet M (2010) Zoonotic aspects of rotaviruses. Vet Microbiol 140: 246-255. Link: https://bit.ly/3eLHqbJ

5. Balvinder KM, Minakshi P, Anju M, Baldev RG, Gaya P (2008) A novel genomic constellation (G10P[3]) of group A rotavirus detected from buffalo calves in northern India. Virus Res 138: 36-42. Link: https://bit.ly/3zoOgxp

6. Tate JE, Burton AH, Boschi-Pinto C, Steele AD, Duque J, et al. (2012) WHO-coordinated Global Rotavirus Surveillance Network. Estimate of worldwide rotavirus-associated mortality in children younger than 5 years before then introduction of universal rotavirus vaccination programmes: a systematic review and meta-analysis. Lancet Infect Dis 12: 136-141. Link: https://bit.ly/3EMiewt

7. Stacy T, Nicola A, Duncan S, Ina P, Nigel AC (2010) Rotavirus Strain Types Circulating in Africa: Review of Studies Published during 1997-2006. J Infect Dis 202: S34-S42. Link: https://bit.ly/32JPQOk

8. Parashar UD, Gibson CJ, Bresee JS, Glass RI (2006) Rotavirus and severe childhood diarrhea. Emerg Infect Dis 12: 304-306. Link: https://bit.ly/3ER3PiC

9. Estes MK, Knipe DM, Howley PM, Griffin DE, Lamb RA, et al. (2001) In: Rotaviruses and their replication, Fields virology. 4th ed. Roizman B, Straus SE, editors. Vol.2. Philadelphia, Pa: Lippincott Williams \&Wilkins 1747-1786.
10. Brandmann T, Jinek M (2015) Crystal structure of the C-terminal 2, 5-phosphodiesterase domain of group A rotavirus protein VP3. Proteins 83: 997-1002. Link: https://bit.ly/32K571L

11. Sue EC, Sasirekha R, Jacqueline ET, Umesh DP, Lennart S, Marie H, et al (2017) Rotavirus infection. Nature Reviews Disease Primers 3: 17083. Link: https://go.nature.com/3FRI6ls

12. Ruiz MC, Theresa L, Yuleima D, Fabian M (2009) Molecular Biology of Rotavirus Entry and Replication. Scientific World Journal 9: 1476-1497. Link: https://bit.ly/3mWp4Js

13. Estes MK, Greenberg HB (2013) Rotaviruses. In Fields Virology 1347-1401, Lippincott Williams Wilkins, Philadelphia, PA, USA, $6^{\text {th }}$ edition $1347-1401$

14. Feng N, Sen A, Wolf M, Vo P, Hoshino Y, et al. (2011) Roles of VP4 and NSP1 in determining the distinctive replication capacities of simian rotavirus RRV and bovine rotavirus UK in the mouse biliary tract. J Virol 85: 2686-2694. Link: https://bit.ly/3qM3ad9

15. Estes MK, Atmar RL (2003) Viral pathogens in the intestine. In: Hecht, G. (Ed.) Microbial Pathogenesis and the Intestinal Epithelial Cell. ASM Press, Washington, DC 525-545

16. Lundgren O, Peregrin AT, Persson K, Kordasti S, Uhnoo I, et al. (2000) Role of the enteric nervous system in the fluid and electrolyte secretion of rotavirus diarrhea. Science 8: 491-495. Link: https://bit.ly/3pRIdyn

17. Hagbom M, Sharma S, Lundgren O, Svensson L (2012) Towards a human rotavirus disease model. Curr Opin Virol 6: 408-418. Link: https://bit.ly/3qM3h8z

18. Mohanty SK, Donnelly B, Bondoc A, Jafri M, Walther A, et al. (2013) Rotavirus replication in the cholangiocyte medi-ates the temporal dependence of murine biliary atresia. Plos One 8: e69069. Link: https://bit.ly/3qJQmnt

19. Hoshino Y, Kapikian AZ (2000) Rotavirus serotypes: Classification and importance in epidemiology, immunity, and vaccine development. J Health Popul Nutr 18: 5-14. Link: https://bit.ly/334yvje

20. Li K, Lin XD, Huang KY, Zhang B, Shi M, et al. (2016) Identification of novel and diverse rotaviruses in rodents and insectivores, and evidence of cross-species transmission into humans. Virology 494: 168-177. Link: https://bit.ly/3mUEfD4

21. Desselberger U, Iturriza-Gómara M, Gray JJ (2001) Rotavirus epidemiology and surveillance. Novartis Found Symp 238: 125-147. Link: https://bit.ly/3mTRhR4

22. Martella V, Banyai K, Matthijnssens J (2010) Zoonotic aspects of rotaviruses. Vet Microbiol 27: 246-255. Link: https://bit.ly/3FRYJUv

23. Cook SM, Glass RI, LeBaron CW, Ho MS (1990) Global seasonality of rotavirus infections. Bull World Health Organ 68: 171-177. Link: https://bit.ly/3pPrCef

24. Banyai K, Laszlo B, Duque J, Steele AD, Nelson EAS (2012) Systematic review of regional and temporal trends in global rotavirus strain diversity in the pre rotavirus vaccine era: insights for understanding the impact of rotavirus vaccination programs. Vaccine 30: 122-130. Link: https://bit.ly/32MXM1p

25. Holland RE (1990) Some infectious causes of diarrhea in young farm animals. Clin Microbiol Rev 3: 345-375. Link: https://bit.ly/32ULcgi

26. Perez E, Kummeling A, Janssen M, Jimenez C, Alvarado R, et al. (1998) Infectious agents associated with diarrhea of calves in the canton of Tilaran, Costa Rica. Prev Vet Med 33: 195-205. Link: https://bit.ly/3ERPdzr

27. Kilgore PE, Unicomb LE, Gentsch JR, Albert MJ, McElroy CA, et al. (1996) Neonatal rotavirus infection in Bangladesh: strain characterization and risk factors for nosocomial infection. Pediatr Infect Dis J 15: 672-677. Link: https://bit.ly/32YjoYz

28. Sue EC, Sasirekha R, Tate JE, Parashar UD, Svensson L, et al. (2017)

Citation: Gichile AG (2022) Review on the epidemiology of Bovine Rotavirus and its public health significance. Int J Vet Sci Res 8(1): 005-010.

DOI: https://dx.doi.org/10.17352/ijvsr.000104 
Rotavirus infection. Nature reviews, disease primers 3: 17083. Link: https://go.nature.com/3pTExw1

29. Barua SR (2019) Clinico-pathology and Molecular characterization of bovine rotavirus infection in calves in south-eastern part of Bangladesh (Doctora dissertation, Department of Pathology and Parasitology Faculty of Veterinary Medicine, Chittagong Veterinary and Animal Sciences University, Chattogram-4225, Bangladesh)

30. Holland RE (1990) Some infectious causes of diarrhea in young farm animals. Clin Microbiol Rev 3: 345-375. Link: https://bit.ly/34kW2Nm

31. Lequin RM (2005) Enzyme immunoassay (EIA)/enzyme-linked immunosorbent assay (ELISA). Clin Chem 51: 2415-2418. Link: https://bit.ly/3FSCL3z

32. Cho Y (2012) Ecology of calf diarrhea in cow-calf operations. Dissertations thesis, IOWA State University, Ames, IA, USA. Link: https://bit.ly/3sRiMyN

33. Malik YSN, Kumar N, Sharma K, Sharma R, Kumar HB,et al. (2013) Epidemiology and genetic diversity of rotavirus strains associated with acute gastroenteritis in bovine, porcine, poultry and human population of Madhya Pradesh, Central India, 2004-2008. Advances in Animal and Veterinary Sciences 1: 111-115. Link: https://bit.ly/3FTp9VU

34. Steele AD, Geyer G H Gerdes (2004) Rotavirus infections. In Infectious Diseases of Livestock, Oxford University Press, Oxford, UK 1256-1264.

35. WHO (2009) Manual of Rotavirus Detection and Characterization Methods. World Health Organization, Geneva, Switzerland. Link: https://bit.ly/3ESqNFR

36. Brandt CD, Kim HW, Rodriguez WJ, Thomas L, Yolken RH, et al. (1981) Comparison of direct electron microscopy, immune electron microscopy, and rotavirus enzyme-linked immunosorbent assay for detection of gastroenteritis viruses in children. J Clin Microbiol 13: 976-998. Link: https://bit.ly/3EMiWtD

37. Lorenz I, Fagan J, More SJ (2011) Calf health from birth to weaning II. Management of diarrhea in pre-weaned Calves. Ir Vet J 64: 9. Link: https://bit.ly/32EEuvj

38. Corl BA, Mathews Oliver SA, Li X, Oliver WT, Ma Y, et al. (2008) Conjugated linoleic acid reduces body fat accretion and lipogenic gene expression in neonatal pigs fed low-or high-fat formulas. J Nutr 138: 449-454. Link: https://bit.ly/3eUjtil

39. Kotloff KL, Nataro JP, Blackwelder WC, Nasrin D, Farag TH, et al. (2013) Burden and aetiology of diarrhoeal disease in infants and young children in developing countries (the Global Enteric Multicenter Study, GEMS): a prospective, casecontrol study. Lancet 382: 209-222. Link: https://bit.ly/3HwgJEj

40. Martella V, Bányai K, Matthijnssens J, Buonavoglia C, Ciarlet M (2010) Zoonotic aspects of rotaviruses. Vet Microbiol 140: 246-255. Link: https://bit.ly/3qEwpP2

41. Izzo M, Kirkland P, Mohler V, Perkins N, Gunn A, et al. (2011) Prevalence of major enteric pathogens in Australian dairy calves with diarrhea. Aust Vet $\mathrm{J}$ 89: 167-173. Link: https://bit.ly/32YGez4

42. Berge A, Moore D, Sischo W (2006) Field trial evaluating the influence of prophylactic and therapeutic antimicrobial administration on antimicrobial resistance of fecal Escherichia coli in dairy calves. Appl Environ Microbiol 72 3872-3878. Link: https://bit.ly/3EPXp35

43. Alam MM, Huque MMA, Nigar S, Haque M, Choudhury NS, et al. (1994) Rotavirus infection in children and calves in association with acute gastroenteritis. Bangladesh Veterinary Journal 28: 35-40.

44. WHO (2013) Rotavirus vaccines WHO position paper: January 2013Recommendations. Vaccine 31: 6170-6171. Link: https://bit.ly/3qKsGQ2

45. Federal Ministry of Health (2015) Comprehensive multi-year plan 2016 - 2020; Federal Ministry of Health, Addis Ababa, Ethiopia. Link: https://bit.ly/3mUECNY
46. Tsion B, Zewdeneh SM, Almaz A, Eshetu L (2004) Rotavirus infection in underfive children in Jima Hospital, Southwest Ethiopia. Ethiop J Health Dev 18. Link: https://bit.ly/3eQzE0a

47. Yassin MA, Kirby A, Mengistu AA, Arbide I, Dove W, et al. (2012) Unusual norovirus and rotavirus genotypes in Ethiopia. Paediatr Int Child Health 32 51-55. Link: https://bit.ly/3mTx9P6

48. Tadesse AA (2012) Hospital-based surveillance of rotavirus gastroenteritis in children less than five years-old: 2007-2011, Addis Ababa, Ethiopia. Fifth International Congress on Infectious Diseases; Bankok, Thailand 16: E146. Link: https://bit.ly/3qKsL6i

49. Getahun K (2014) Effect of Concentrate Supplementation on Performances of Ethiopian Lowland Afar and Blackhead Ogaden Lambs. Animal and Veterinary Sciences 2: 36-41. Link: https://bit.ly/3FSyi15

50. Gelaw A, Pietscha C, Liebert UG (2018) Molecular epidemiology of rotaviruses in Northwest Ethiopia after national vaccine introduction. Infect Genet Evol 65 300-307. Link: https://bit.ly/3mW4xoC

51. Woyessa AB, Abebe A, Beyene B, Tefera M, Assefa E, et al. (2019) Rotavirusassociated acute diarrhea outbreak in West Shewa Zone of Oromia Regional State, Ethiopia 2017. Pan Afr Med J 32: 202. Link: https://bit.ly/3zmzyXN

52. Abebe A, Getahun M, Mapaseka SL, Beyene B, Assefa E, et al. (2018) Impact of rotavirus vaccine introduction and genotypic characteristics of rotavirus strains in children less than 5 years of age with gastroenteritis in Ethiopia: 2011-2016. 36: 7043-7047. Link: https://bit.ly/3eKxBee

\section{Discover a bigger Impact and Visibility of your article publication with Peertechz Publications}

\section{Highlights}

* Signatory publisher of ORCID

* Signatory Publisher of DORA (San Francisco Declaration on Research Assessment)

* Articles archived in worlds' renowned service providers such as Portico, CNKI, AGRIS, TDNet, Base (Bielefeld University Library), CrossRef, Scilit, J-Gate etc.

* Journals indexed in ICMJE, SHERPA/ROMEO, Google Scholar etc.

* OAI-PMH (Open Archives Initiative Protocol for Metadata Harvesting)

* Dedicated Editorial Board for every journa

* Accurate and rapid peer-review process

* Increased citations of published articles through promotions

- Reduced timeline for article publication

Submit your articles and experience a new surge in publication services (https://www.peertechz.com/submission).

Peertechz journals wishes everlasting success in your every endeavours.

Citation: Gichile AG (2022) Review on the epidemiology of Bovine Rotavirus and its public health significance. Int J Vet Sci Res 8(1): 005-010. DOI: https://dx.doi.org/10.17352/ijvsr.000104 